\title{
Hesitantly towards mutual recognition of "vaccination passports". A survey on potential ubiquity in administrative law ${ }^{1}$
}

Associate professor Jakub HANDRLICA ${ }^{2}$

\begin{abstract}
The problem of potential ubiquity emerged in administrative law because of transboundary circulation of various certificates, licences and permits. These documents, approving certain facts, may appear before an administrative authority of another State. Thus, the applicable regime of public law must qualify the legal consequences of such documents in the realm of the applicable administrative law. This article aims to discuss this problem with regard to the challenges arising in the second year of the COVID-19 pandemics. Prospective introduction of "immunity certificates" and "vaccination passports" in various jurisdictions and the need to establish mutual recognition of such "passports" and "certificates" is the subject of attention. The article points out existence of several dogmatic approaches to the fact that foreign administrations have either approved a fact, or granted a right. Some of these dogmatic approaches have been reflected in the written law. However, at the same time, in theory, other solutions than those provided by the current legal framework would also be theoretically possible. The importance of these theoretical considerations is demonstrated regarding the very current discussions on the introduction of "immunity certificates" and "vaccination passports".
\end{abstract}

Keywords: potential ubiquity; international administrative law; unilateral recognition; mutual recognition; immunity certificates; vaccination passport; COVID-19 pandemics.

JEL Classification: K23, K32

DOI: $10.24818 / \mathrm{TBJ} / 2021 / 11 / \mathrm{SP} / 01$

\section{Introduction}

My highly esteemed colleague, Associate Professor Radomír Jakab from the Law Faculty, University in Košice, Slovakia, published an interesting article ${ }^{3}$ on mutual recognition of administrative acts in the special issue of this journal last year. In his article, he summarised the recent EU law governing mutual recognition of certain administrative acts under the "Union of Composite Administration". The author in particular addressed the questions of review of such administrative acts. This coves both the measures serving for the protection of the public interest of the concerned Member States as well as the potential measures a private entity would use against a foreign act, which is deemed to be unlawful.

${ }^{1}$ This research was funded by Czech Science Agency through its project 20-01320S "International Administrative Law: Legal Discipline Rediscovered".

2 Jakub Handrlica - associate professor of administrative law, Faculty of Law, Charles University, Prague, Czech Republic; visiting fellow, European Law and Governance School, Athens, Hellenic Republic, jakub.handrlica@prf.cuni.cz,https://orcid.org/0000-0003-2274-0221.

${ }^{3}$ Radomír Jakab, "Defense of an EU member state aganst effects of transnational administrative acts," Tribuna Juridica - Juridical Tribune 10, Special issue (September 2020): 32-48. 
The problems, as analysed in the Radomír Jakab article, call for urgent further attention by the scholarship of administrative law. The fact is that since his article was published, discussions about potential introduction of the "immunity certificates" and the "vaccination passport" have taken centre stage. Due to the global nature of the COVID-19 pandemics, these discussions are taking place at both global and regional levels. These discussions again trigger the interest of legal scholarship in the problems of recognition in administrative law. The fact is that any prospective "immunity certificates", or "vaccination passports" will represent a product of national administrations, but their effects and impact will inevitably be of a transboundary nature. Consequently, the topic represents a fertile ground for research in administrative law and in particular in the field labelled as "international administrative law". ${ }^{4}$

With regard to the current discussions on the forthcoming introduction and recognition of "immunity certificates" and "vaccination passports" 5 , this article aims to contribute to these discussions, as well as analysing the theoretical aspects of this feature. While Radomír Jakab analysed the primary written provisions of existing law in his article, this article aims to identify various theoretical approaches to the problem of recognition in administrative law. With respect to the discussions concerning an introduction of "vaccination passports", various States may opt for different approaches to the introduction of such passports for their own citizens and to the problem of recognition of passports issued by other States. ${ }^{6}$ The fact is that several options are now open and various approaches are potentially possible.

\footnotetext{
${ }^{4}$ See Jakub Handrlica, "A treatise for international administrative law", Lawyer Quarterly 10, no. 4 (December 2020): 462-475.

${ }^{5}$ See Tasnime Osama, Mohammad S. Razai, Azeem Majeed, "Covid-19 vaccine passports: Access, equity and ethics", The BMJ 373 (April 2021): n861, Inigo de Miguel Beriain and Jon Rueda, "Vaccination certificates, immunity passports and test-based travel licences: Ethical, legal and public health issues", Travel Medicine and Infectious Disease 42 (July 2021): 102079, Kevin K. Tsoi et al, "The way forward after COVID-19 vaccination: Vaccine passports", BMJ Innovations 7, no. 2 (April 2021): 337-341, Rebecca C. H. Brown, Julian Savulescu and Bridget Williams, "Passport to freedom? Immunity passports for COVID-19”, Journal of Medical Ethics 40, no. 10 (October 2020): 652-659, Inigo de Miguel Beriain and Jon Rueda, "Immunity passports, fundamental rights and public health hazards", Journal of Medical Ethics 46, no. 10 (October 2020): 660-661, Alexra L. Phelan, "COVID19 immunity passports and vaccination certificates: scientific, equitable and legal challenges," The Lancet 395, no. 10237 (May 2020): 1595-1598, Govind Persad and Ezekiel Emanuel, "The Ethics of COVID-19 Immunity-Based Licenses ("Immunity Passports")," Journal of American Medical Association 323, no. 22 (June 2020): 2241-2242, Natalie Kofler and Francis Baylis, "Examining "immunity passports" from an ethics perspective - ten reasons why they are a bad idea," European Journal of Public Health 30, supplement 5 (September 2020): V185-V185 etc.

${ }^{6}$ In February 2021, Greece and Israel announced desire to enter into a bilateral agreement, which would provide for a mutual recognition of "vaccination passports" ("green passes") issued by the competent authorities of either State and which would entitle the holder of such passport to enter and move freely the respective State, without any self-isolation or any other way of limitation. At the same time, several States (e.g. Denmark, Iceland, Estonia, Spain, Bahrain, the United Arab Emirates) have announced starting works towards issuing "vaccination passports" to their own citizens. Hawaii announced to launch a project of its own "vaccination passport", which will serve US citizens from other States to enter its territory. The push by governments is further spurred by initiatives from the private sector, with tech giants including Microsoft and Oracle teaming up with travel industry associations such as IATA to create new "global digital health passes".
} 
The aim of this article is to analyse these options and present their advantages and disadvantages from a viewpoint of administrative law. Also, this article aims to reflect the state of art regarding the prospective introduction of the "vaccination passports", as existing in half of the second year of the COVID-19 pandemic. Despite major negative considerations ${ }^{7}$ expressed against the introduction of "vaccination passports", several States have already introduced bilateral regimes of mutual recognition of these documents as a rection to the mere necessity. However, at the moment this article was finished, any regional or global regime in this field was still missing. ${ }^{8}$

\section{The problem of potential ubiquity in administrative law}

The feature of potential ubiquity, meaning its presence everywhere or in many places simultaneously (omnipresence) has traditionally been a subject of attention for the scholarship of private law. ${ }^{9}$ This concerned ownership rights in particular, as objects of ownership are potentially present everywhere and legal relations to them must be settled.

The fact is, however, that the problem of potential ubiquity may also appear in the field of administrative law. Certain facts may be approved, or rights may be granted by the competent administrative authorities of sovereign States. Consequently, such administrative authorities issue a document that can be referred to under the umbrella term "administrative act". Such administrative acts may subsequently circulate among the other States. Consequently, the administrative authorities of these States may deem necessary to evaluate whether such approval of facts, or granting certain rights, gain any effects in the sphere of their applicable law. ${ }^{10}$

${ }^{7}$ See eg. Henry T. Greely, "COVID-19 immunity certificates: science, ethics, policy and law”, Journal of Law and the Biosciences 7, no. 1 (June 2020): Isaa0035.

${ }^{8}$ At the moment this article was finished, a project of an EU "vaccination passport" was still under discussion. In March 2021, an information was presented that such "passport" will not only certify the fact, its holder was vaccinated, but will also attest the COVID-19 negativity approved by a PCRtest. For further details on the state of discussions in the moment, this article was finished, see Alberto Alemanno, "The European Response to COVID-19: From Regulatory Emulation to Regulatory Coordination", European Journal of Risk Regulation 11, no. 2 (June 2020): 307-316 and Alessio M. Pacces, Maria Weimer, "From Diversity to Coordination: A European Approach to COVID-19", European Journal of Risk Regulation 11, no. 2 (June 2020): 283-296. Concerning regulation on the global level, see Eskild Petersen, Daniel Lucey, Lucille Blumberg et al, "COVID-19 vaccines under the International Health Regulations - We Must Use the WHO International Certificate of Vaccination or Prophylaxis", International Journal of Infectious Diseases 104 (March 2021): 175177 (here, authors are arguing in favour of using if the carte jaune [yellow card], as introduced by the WHO, as "vaccination passport" for the COVID-19 vaccination).

9 Paul Babie, "The Future of Private Property", Sydney Law Review 40, no. 3 (September 2018): 433-444. Also see David Campbell, "Good Faith and the Ubiquity of the "Relational' Contract", The Modern Law Review 77, no. 3 (May 2014): 475-492 and Frank P. Maier-Rigaud, "Umbrella effects and the ubiquity of damage resulting from competition law violations", Journal of European Competition Law and Practice 5, no. 4 (April 2015): 247-251.

${ }^{10}$ Jakub Handrlica, "Revisiting international administrative law as a legal discipline", Zbornik Pravnog Fakulteta Sveučilišta u Rijeci 39, no. 3 (December 2018): 1238-1239. 
The fact is, however, that the respective document merely represents an attestation that foreign authority has either granted a certain right (driving licence, university diploma, pilot licence), or approved a certain fact (a passport, approving citizenship of certain State). Here, one may refer to the current discussion on the introduction of "vaccination passports", which would certify the vaccination of the holder of such a passport against COVID-19. While the potential introduction of a "paper version" of such a "passport" would correspond to the very traditional approach to attest a certain fact, the introduction of digital certificates seems both more practical and probable. ${ }^{11}$ Irrespective of the form of the document, it is not the document itself, but rather the subject of approval, or granting of certain right in the sphere of public rights, which is to be recognised. This problem has many historical parallels. The scholarship has referred to the issue of circulation of university diplomas, obtained at a foreign university in medieval Europe,${ }^{12}$ to "recognition" of certificates approving certain special skills by medieval guilds, ${ }^{13}$ etc. ${ }^{14}$ Finally, the currently announced plans of several States to issue "vaccination passports" to their own citizens has clear parallels in the practice to issue "safe-conduct instruments" (sauf-conduit, or guidaticum) ${ }^{15}$ and in the various international certificates (carte jaune, yellow card), approving vaccination against cholera, yellow fewer, smallpox and typhus. ${ }^{16}$

The overall approach of other public administrations to the fact that other States approved certain facts, or granted certain rights, has been labelled by the term "recognition" in legal scholarship. ${ }^{17}$ However, the term "recognition", though firmly established and widely used in this context, may be somewhat confusing and ambiguous. ${ }^{18}$ In the traditional theory of public law, cases involving two legal systems could always be considered as exceptional compared to all legal

${ }^{11}$ See Marc Eisenstadt, Manoharan Ramachandran, Niaz Chowdhury, Allan Third and John Dominique, "COVID-19 Antibody Test/Vaccination Certification: There is an App for That", IEEE Open Journal of Engineering in Medicine and Biology 1, no. 1 (June 2020): 148-155 and Klaus Marhold, Jan Fell, "Electronic vaccination certificates", Nature Medicine, available at 10.1038/s41591-021-01286-w.

${ }^{12}$ Richard W. Southern, "The Changing Role of Universities in Medieval Europe", Historical Research 60, no. 142 (June 1987): 133-146.

${ }^{13}$ Christian Jarck, Abänderung und Aufhebung ausländischer Staatshoheitsakte im internationalen Rechtsverkehr (Göttingen: Georg-August Universität, 1954), 12-14.

${ }^{14}$ Recognition of baptismal certificates between the Catholic Church and the Orthodox Churches do represent another salient parallel. Also here, a fact whether the baptism was proceeded in the name of the Holy Trinity is matter of review, not the certificate itself. See Dagmar Heller, "Toward One Baptism: The Discussions on Mutual Recognition of Baptism in an International Perspective", Ecumenical Review 67, no. 3 (October 2015): 436-449 and Timothy L. T. Ngern, "One Baptism: Towards Mutual Recognition", Journal of Ecumenical Studies 49, no. 2 (September 2014): 362-363.

${ }^{15}$ See Mark B. Salter, Rights of Passage: The Passport in International Relations (London: Lynne Rienner Publishers, 2003), 13.

${ }^{16}$ See Annelies Wilder-Smith and D. R. Hill, "International certificate of vaccination or prophylaxis", The Lancet 370, no. 9587 (August 2007): 565-566 and Aaron T. Hunt, "Authentication of international vaccination certificates", British Medical Journal 2, no. 5869 (1973): 781-782.

${ }^{17}$ See Matthias Ruffert, "Recognition of Foreign Legislative and Administrative Acts", in Max Plack Encyclopedia of Public International Law, ed. Rüdiger Wolfrum (Oxford: Oxford University Press, 2008), 567-578.

${ }^{18}$ Ibid, 568. 
relationships in general. Thus, one line of scholarship of administrative law has systematically argued that only the norm of the applicable domestic law may provide for any effects of a foreign administrative act in inland.

This line of scholarship was represented in particular by the academic works authored by Karl Neumeyer. ${ }^{19}$ Neumeyer was a strict follower of the dualistic theory, which rigorously followed the distinction between international law on one hand and domestic law on the other. Consequently, Neumeyer argued that it depends entirely on the norm of domestic law, whether certain approval of facts, or granting of a right will gain any effects in the sphere of domestic law. In this regard, the feature of "recognition" represented a realm of its own, separated from international law and thus, from any reciprocity. ${ }^{20}$ Whether a person entitled to drive a car may use this right inland, whether a captain may steer the ship on inland rivers, whether a holder of diploma from a foreign university may practice his profession inland - all these facts depended, as Neumeyer argued, entirely on domestic legislation. This dogmatic approach to recognition has been widely reflected in the subsequent scholarship. ${ }^{21}$

Another line of academic scholarship has argued for the concept of "an opened Statehood". Here, it was Klaus Vogel in particular, who claimed ${ }^{22}$ that a norm of domestic (administrative) law does not necessary represent the only and exclusive source of recognition. Certain facts are to be recognised as based on international custom, on international comity, based on a pure necessity, or on common sense. Reflecting the current situation, one may demonstrate this approach on the following situation: A person has been fully vaccinated in the State "A" and obtained a "vaccination passport" from the competent authority. Afterwards, this person moved to State "B", whereas any mutual recognition of "vaccination certificates" is missing among these two States. The fact that the legal framework applicable in State " $B$ " does not provide for any recognition of the existing "vaccination passport" does imply that the person is to be qualified as "nonvaccinated" in State "B". However, such legal qualification can not change the fact, the person has been vaccinated and thus, gained immunity against COVID-19. The concept of "an opened Statehood" would allow a more practical approach here, that could reflect the reality of life more efficiently.

More recently, Matthias Ruffert argued ${ }^{23}$ in his entry on recognition in the Max Plack Encyclopedia of Public International Law: "In our time, such cases are an everyday occurrence, and they can be tackled with the idea of recognition, which

${ }^{19}$ Karl Neumeyer, Internationales Verwaltungsrecht. Allgemeiner Teil (München: Verlag J. Schweitzer, 1936), 185-186.

${ }^{20}$ See Jakub Handrlica, “Two faces of ,international administrative law”, Tribuna Juridica - Juridical Tribune 9, no. 2 (April 2019): 375-376.

${ }^{21}$ See e.g. Christoph Oehler, Die Kollisionsordnung des Allgemeinen Verwaltungsrecht. Strukturen des deutschen Internationalen Verwaltungsrechts (Tübingen: Mohr Siebeck, 2019) and Adrian Hemler, Die Methodik der ,Eingriffsnorm “ im modernen Kollisionsrecht (Tübingen: Mohr Siebeck, 2019).

22 Klaus Vogel, Der räumliche Anwendungsbereich der Verwaltungsnorm. Eine Untersuchung über die Grundlagen des sog. Internationalen Verwaltungs- und Steuerrechts (Frankfurt/Main: Alfred Metzner Verlag, 1965), 142-148.

${ }^{23}$ Ruffert "Recognition of Foreign Legislative and Administrative Acts", 570. 
becomes practically relevant or even controversial only in some typical cases (eg recognition of an act granting nationality or recognition of an act of expropriation). However, it must be noted that the interrelation between legal systems has increased considerably until today. The 'recognition' of foreign legal acts is desired in the context of many modern international legal regimes. Thence, the idea of explicit recognition in each of the newly arising various cases might appear outdated, and in legal scholarship the perspective has shifted towards the idea of transnationality." 24

The fact is that both above-mentioned dogmatic approaches to the problem of "recognition" were reflected in the law and in the administrative practice of the concerned States. On one hand, the notion of "recognition" is being regularly provided by the applicable provisions of domestic legislation. In the case of such a provision, providing for a recognition of foreign "immunity certificate", or "vaccination passport" is missing, a consequent application of the dogmatic approach as developed by Neumeyer would lead to a situation where the competent authorities will simply not consider a foreign document as a valid one. Consequently, under this approach, a person who was dully vaccinated in one State may be considered non-vaccinated by the applicable regime of public law of another State.

In this respect, one may argue that the approach based on rigid requirement for a written provision, providing for recognition, may lead to major discrepancies between the world of facts and the world of law. Such discrepancies, in particular when existing among States using the same types of vaccines, may imply severe problems and may cause decrease of trust in the efficiency of the legal order.

At the same time, the practice of administrative authorities also regularly involves the "recognition" of facts that have occurred abroad and have been not explicitly provided by domestic legislation. In the course of the COVID-19 pandemics, the administrations of States worldwide had to face the challenge of qualifying foreign "immunity certificates" and "vaccination passports". Should any written piece of legislation on "recognition" of such documents be missing, several States opted spontaneously to "recognise" these documents, based on their authenticity and mutual (or at least unilateral) trust. ${ }^{25}$

Consequently, one may argue that during the COVID-19 pandemics, both above-mentioned dogmatic approaches have been reflected in administrative practice in parallel.

\section{The perils of unilateral and mutual recognition in administrative law}

Neither of these dogmatic approaches to the problem of "recognition", as analysed above, has denied the fact that a State may opt for a regime of unilateral

\footnotetext{
${ }^{24}$ See also Giacinto Della Cananea, "Transnational public law in Europe: Beyond the lex alius loci”, in Transnational law, eds. Miquel Maduro, Kaarlo Tuori and Suvi Sankari (Cambridge: Cambridge University Press, 2014): 321-345.

25 See Chee H. Liew, Gerard T. Flaherty, "Immunity passports to travel during the COVID-19 pandemic: controversies and public health risks", Journal of Public Health 43, no. 1 (March 2021): e135-e136.
} 
recognition. As a matter of principle, a "recognition" is per se not necessarily linked to any reciprocity. ${ }^{26}$ A State may opt for unilateral recognition based on its own sovereignty. That means the public administration of such a State will not evaluate whether a certain fact exists or does not exist, but will merely accept the result of an evaluation done abroad by a competent administrative authority.

The fact is that opting for unilateral recognition might be seen as the surrender of a certain portion of administrative competences. ${ }^{27}$ Thus, opting for unilateral recognition - without a desire to achieve reciprocity - could be classified as opting for an unequal position. ${ }^{28}$ However, the practical experiences in the period of COVID-19 pandemics show that a great number of States that are major tourist destinations are spontaneously prepared to unilaterally recognise documents issued by foreign authorities, approving immunity by COVID-19 "immunity certificates". ${ }^{29}$

So, in practical terms, opting for unilateral recognition must not necessary imply "surrendering of administrative competences", but rather a relief of administrative burden on the side of the concerned State. Consequently, the method of unilateral recognition may represent a very flexible and effective approach to address certain specific situations of emergency. ${ }^{30}$ In the future, unilateral recognition of various forms of "vaccination passports" may represent a viable option for those States that will aim to both enable their domestic tourist sector to gain profit from the influx of foreigners and guarantee a certain degree of safety for their domestic population and visitors.

On the contrary, the regime of "mutual recognition" requires agreement on certain common minimal standards. ${ }^{31}$ In principle, "mutual recognition" in administrative law requires common acceptance of certain minimal standards of material and procedural rules. Reflecting the current discussions on mutual recognition of "vaccination passports", one must bear in mind that it is not the "passport" (in paper or electronic form), which is to be recognised. The subject of recognition is the fact that a vaccination was done correctly. In fact, several regimes of mutual recognition concerning various types of "vaccination passports" have existed in the past and also exist currently. The first regimes of mutual recognition of vaccination certificates were established by the International Sanitary Convention

${ }^{26}$ See Francesco Parisi and Nita Ghei, "The role of reciprocity in international law", Cornell International Law Journal 36, no. 1 (September 2003): 93-123.

${ }^{27}$ See Eleanor Spaventa, "Mutual recognition and conflict of law rules", Common Market Law Review 40, no. 6 (December 2003): 1562-1564 and Thomas Streinz, "The Principle of Mutual Recognition in EU Law", Journal of Common Market Studies 52, no. 5 (September 2014): 1166-1167.

${ }^{28}$ See Wolfgang Kerber and Roger Van den Bergh, "Mutual Recognition Revisited: Misunderstandings, Inconsistencies, and a Suggested Reinterpretation", Kyklos 61, no. 3 (August 2008): 460-461.

${ }^{29}$ Schlagenhauf, P., Patel, D., Rodriquez-Morales, A., Gautret, P., Grobusch, M., Leder, K. "Variants, vaccines and vaccination passports", Travel Medicine and Infectious Disease 40, article number 101996 (March 2021): https://doi.org/10.1016/j.tmaid. 2021.101996.

30 See Bertrand du Marais, "Le »Grand Évitement« et le droit administratif", in Le futur du droit administratif. The future of administrative law, eds. Jean-Bernard Auby, Émilie Chevalier and Emmanuel Slautsky (Paris: SciencesPo and Lexis Nexis, 2019), 527-548.

${ }^{31}$ Kenneth A. Armstrong, "Mutual Recognition", in The Law of the Single European Market, eds. Catherine Barnard and Joanne Scott (Oxford: Hart Publishing, 2002), 225-268. 
for Aerial Navigation. ${ }^{32}$ The subsequent Amendment, adopted in 1944, introduced five various types of certificates ${ }^{33}$ that were to be used in both aerial and maritime travel. Later, these various types of certificates were replaced by the International Certificate of Vaccination or Prophylaxis (ICVP), also known as carte jaune, or the yellow card. Currently, the $3^{\text {rd }}$ version of International Health Regulations, as issued by the WHO in 2005 , provide rules on the ICVP. ${ }^{34}$

Thus, a potential introduction of mutual recognition of COVID-19 "vaccination passports" has several major preconditions: Firstly, the common agreement on the list of vaccines, which will be considered as safe, is to be reached among the concerned States. This is a material requirement of any mutual recognition. ${ }^{35}$ Here, the States entering into an agreement will recognise that a vaccination that occurred in the other State fulfils the common minimal criteria and that the State is prepared to grant the person vaccinated there the same rights as its own citizens vaccinated inland. ${ }^{36}$ Secondly, a mutual trust in the efficiency of administrative proceedings that led to the issue of "passports" represents a major precondition for any "mutual recognition". ${ }^{37}$ Further, there must be an agreement on the form of such "passport" and such form must guarantee its transparency (in particular concerning their content and language used) as well as resistance to any falsification. ${ }^{38}$

The reality of the second year of the COVID-19 pandemics clearly shows that those agreements referred in the previous paragraph can more easily be reached at bilateral, rather than regional levels. In March, 2021, Greece and Israel entered into an agreement recognising "vaccination passports" (referred also as "green cards") issued in either of the States and allowing mutual travel of up to 10,000 persons a month. In May 2021, several States of Central Europe ${ }^{39}$ entered into bilateral agreements, providing for mutual recognition of "vaccination certificates". Entering into these agreements reflected both increasing numbers of vaccinated persons in these States and the absence of any legal framework on mutual recognition under EU law. Consequently, these States decided to establish their own bilateral regimes of mutual recognition. The fact is, however, that rather than a

32 The International Sanitary Convention on Aerial Navigation (adopted on $12^{\text {th }}$ April 1933, entered into force on $1^{\text {st }}$ August 1935).

${ }^{33}$ International certificate of inoculation against cholera, international certificate of inoculation against yellow fever, international certificate of immunity against yellow fever, international certificate of inoculation against typhus fever, international certificate of vaccination against smallpox.

${ }^{34}$ See Annex 6 of the International Health Regulations.

${ }^{35}$ Armstrong, "Mutual Recognition", 226.

${ }^{36}$ See Brown, Savulescu, Williams, "Passport to freedom? Immunity passports for COVID-19", 653-654

${ }^{37}$ For further details, see Florentino-Gregorio Ruiz-Yamuza, "Requiem for the principle of mutual trust?" Revista general de derecho europeo 20, no. 43 (October 2017): 201-245.

${ }^{38}$ For further details in these arrangements, see Eisenstadt, Ramachandran, Chowdhury, Third, Dominique, "COVID-19 Antibody Test/Vaccination Certification: There is an App for That", 148-155.

${ }^{39}$ Federal Republic of Germany, the Czech Republic, Poland, Austria, Slovenia and Hungary. For the time being, all these States use to issue their own ,vaccination certificates“, which are both in English and in their official language. Lack of English text on the vaccination certificates, issued by the authorities of the Slovak Republic was the reason, why a similar agreement was not established also with this State. 
coherent framework for mutual recognition, these agreements provided a patchwork of parallel existing regimes of mutual recognition. Two remarks can be made to illustrate this patchwork:

Firstly, each of the agreements follows its own time schedule concerning the validity of the vaccination. While the agreement concluded between the Czech Republic and the Federal Republic of Germany provides that vaccination will be mutually recognised, in two weeks time after the second vaccination, the agreement between the Czech Republic and Slovenia requires merely passing of one week. Also, the agreement concluded between the Czech Republic and Austria also foresaw that entry to the territory of the State will be allowed only when 22 days after the first vaccination have passed.

Secondly, the concluded agreements fail to establish any uniform template of the "vaccination passport". In principle, they merely rely on mutual recognition of those documents, issued by the competent authorities of either of the Contracting Parties of the respective agreement.

Consequently, establishing a patchwork of these parallel existing recognition regimes may be interpreted as another outcome of the phaenomena that has been labelled "vaccination nationalism" in academy. ${ }^{40}$ At the same time, the need for a more complex solution seems to be inevitable. The "Union of Composite Administration", as established by the means of EU law, offers an efficient platform to cope with the challenges arising. A regulation, as a directly applicable source of EU law, offers means for introduction of an efficient system of mutual recognition of "vaccination passports" among EU member States. Such a system has the capacity to overcome the emerging system of bilateral agreements among the various Member States.

\section{Review of foreign "immunity certificates" and "vaccination passports"}

The problem of review of foreign administrative acts, as discussed by Radomír Jakab in his above-mentioned article ${ }^{41}$, must therefore be analysed from two theoretical viewpoints:

Firstly, there is the viewpoint of unilateral recognition. If a State opts to unilaterally recognise that a foreign authority has granted a right, or approved a certain fact, it will remain up to this State to also review such a fact. Consequently, under the regime of unilateral recognition, the possibility to "review foreign administrative acts" is open and may lead to denial of the claimed rights. This would be manifested in the form of a "cancelation" of the foreign document. Such cancellation will only concern the territory of the State and has by no means any

40 See David P. Fidler, "Vaccine nationalism's politics”, Science 369, no. 6505 (August 2020): 749-755. Also see Lukasz Gruszczynski, Chien-huei Wu, "Between the High Ideals and Reality: Managing COVID-19 Vaccination Nationalism”, European Journal of Risk Regulation, available at: https://doi.org/10.1017/err.2021.9.

${ }^{41}$ Jakab, "Defense of an EU member state aganst effects of transnational administrative acts," 32-48. 
effect for the legal framework of the home State. One may remember that it was the French scholarship that has traditionally argued in favour of the possibility to proceed in this way in order to guarantee the public interest of the State ${ }^{42}$ Thus, the regime of unilateral recognition and potential review of foreign acts are - in principle - interlinked.

Having this perspective in mind, one can hardly defend the argument that the regime of unilateral recognition implies any "limitation" of sovereignty. If a State has opted ${ }^{43}$ for unilateral recognition of "immunity certificates" issued abroad, or will in future opt for unilateral recognition of foreign "vaccination passports", its powers to review such documents will remain and could be still used as a measure of emergency. This is, obviously, a very strong argument to not rely on unilateral recognition of such "passports", but to facilitate their recognition by a formal agreement.

Consequently, the second viewpoint is that of mutual recognition. The fact is that when referring to the regime of mutual recognition, the pure form of such regime would exclude any possibility for review or cancellation of the foreign act. ${ }^{44}$ In regard to the potential introduction of mutual recognition of "vaccination passports", such a possibility would also be possible. In such a regime, the recognising State will have no possibility to review foreign "passports", even in the case of serious doubts. However, one can express serious doubts whether such approach will be viable and acceptable for the concerned States.

Thus, facing the challenge to introduce mutual recognition of "vaccination passports", several options for handling foreign "passports" may be discussed and subsequently introduced into the written legislation. Here, we must distinguish two aspects of this problem. Firstly, the destination State may have doubts about the immunity gained by vaccination and desires additional verification of such immunity. Another situation may arise in doubts not with respect to the impact of vaccination, but to the "vaccination passport" (i.e. attestation itself).

Firstly, the recipient State may be granted the right to provide for any additional verification of the facts approved by the passport, for example in the form of random testing. The fact is, however, that only when such additional verification is introduced as an emergency measure, may the regime of mutual recognition gain its full effects.

${ }^{42}$ See Karine J. Delvolvé, "L'évolution du principe de reconnaissance mutuelle”, in La reconnaissance mutuelle comme instrument de globalisation juridique, ed. Hervé A. Prince (Montréal: Éd. Yvon Blaise, 2016), 36-37.

${ }^{43}$ As of March 2021, Georgia and Seychelles have already announced that they will allow the proof of vaccination (a "vaccination passport") as an alternative to existing testing and quarantine requirements. In May 2021, Greece officially opened the touristic season and announced, that it will allow those tourists from other EU Member States, possessing "vaccination certificates" from their home States, under the precondition that two weeks since the $2^{\text {nd }}$ vaccination have lapsed. Such declaration may be classified as a unilateral recognition, as any formal agreements between Greece and other EU Member States are missing for the time being.

${ }^{44}$ Jakub Handrlica, "Is there an EU international administrative law? A juristic delusion revisited", European Journal of Legal Studies 12, no. 2 (October 2020): 110-111. 
Secondly, situations may occur where doubts will arise concerning the authenticity of the "vaccination passport". For example, if the $3^{\text {rd }}$ version of the International Health Regulations, which currently regulate the regime of the carte jaune (International Certificate of Vaccination or Prophylaxis), do not provide any rules enabling the destination State to review such authenticity. In practice, several States which have faced the prevalence of counterfeit certificates ${ }^{45}$, opted for the introduction of digital certificates. These risks currently represent the main argument against use of the carte jaune as a "vaccination passport" with respect to the COVID19 vaccination. ${ }^{46}$

Further, a regime enabling a review and a subsequent withdrawal of foreign "vaccination passport" would theoretically be possible. One must bear in mind that such a measure must represent a kind of ultima ratio and should be used only in very extreme situations of fraud or intentional criminal activities. A parallel exists in the regime of withdrawal of foreign driving licences, as provided by the Vienna Convention on the Road Traffic. In this regard, it is interesting to note than neither of the bilateral agreements, as mentioned above in part 3, provide for any competence of a Contracting Party to review, or withdraw a foreign "vaccination passport".

When drafting the future agreements on mutual recognition of "vaccination passports", the Contracting Parties of such agreements will be in a delicate position to balance their interests. The same applies vis-á-vis any prospective EU legislation in this field:

On one hand, there will be interest in facilitating the mutual circulation of persons. To promote this interest, the Contracting Parties will be expected to recognise "vaccination passports" as issued by the other Party without any major limitations.

On the other hand, each prospective Contracting Party will also face the need to guarantee public health and security. Therefore, the agreements, or a prospective EU regulation on mutual recognition of "vaccination passports" may also potentially include some of the measures outlined above.

\section{Conclusions}

The problem of potential ubiquity has emerged in administrative law because of the transboundary circulation of various certificates and attestations. A foreign document may appear in relations governed by the administrative authority. Thus, the applicable regime of public law must qualify the legal consequences of such acts in the realm of domestic law. This article aims to identify the existence of several dogmatic approaches to the fact that a foreign administration has either approved a fact, or granted a right. The importance of these theoretical considerations can be demonstrated regarding the extremely current discussions on the introduction of "vaccination passports" with regard to COVID-19 pandemics.

45 This was the case of Zambia, Zimbabwe and Nigeria.

46 See Petersen, Lucey, Blumberg et al, "COVID-19 vaccines under the International Health Regulations - We Must Use the WHO International Certificate of Vaccination or Prophylaxis” 175. 
At the time this article was finished, several regimes of recognition of "immunity certificates" and "vaccination passports" existed in parallel. Several States opted for a regime of unilateral recognition of foreign certificates. At the same time, those States, wishing to facilitate mutual circulation of their citizens, first entered into bilateral agreements on recognition of "vaccination passports". A patchwork of the rules established clearly calls for a more coherent regional framework. At the same time, the developments demonstrate that a bilateral approach to mutual recognition seems to be more flexible than establishing of regional regimes.

At this stage, however, one can predict the emergence of new regional regimes of mutual recognition of "vaccination passports", which will overcome the disadvantages of merely bilateral solutions. Such regional regimes will need to facilitate two divergent interests: on one hand, the interests of free and undisturbed circulation of vaccinated persons and on the other, the interests of guaranteeing a high degree of public health and safety that may lead to the introduction of certain measures, which will limit the effects of "vaccination passports" and enable their review by the State of destination.

\section{Bibliography}

1. Alemanno, A. "The European Response to COVID-19: From Regulatory Emulation to Regulatory Coordination?" European Journal of Risk Regulation 11, no. 2 (June 2020): 307-316.

2. Armstrong, K. "Mutual Recognition." In The Law of the Single European Market, edited by C. Barnard and J. Scott, 225-268. Oxford: Hart Publishing, 2002.

3. Babie, P., "The Future of Private Property", Sydney Law Review 40, no. 3 (September 2018): 433-444.

4. Brown, R., Savulescu J., Williams, B. "Passport to freedom? Immunity passports for COVID-19." Journal of Medical Ethics 40, no. 10 (October 2020): 652-659.

5. Della Cananea, G. "Transnational public law in Europe: Beyond the lex alius loci", In Transnational law, edited by Miquel Maduro, Kaarlo Tuori and Suvi Sankari, 321-345. Cambridge: Cambridge University Press, 2014.

6. Delvolvé, J. "L'évolution du principe de reconnaissance mutuelle", In $L a$ reconnaissance mutuelle comme instrument de globalisation juridique, edited by Hervé A. Prince, 36-48. Montréal: Éd. Yvon Blaise, 2016.

7. Du Marais, B. "Le »Grand Évitement« et le droit administratif", In Le futur du droit administratif. The future of administrative law, edited by Jean-Bernard Auby, Émilie Chevalier and Emmanuel Slautsky, 527-548. Paris: SciencesPo and Lexis Nexis, 2019.

8. Eisenstadt, M., Ramachandran, M., Chowdhury, N., Third, A., Dominique, J. "COVID19 Antibody Test/Vaccination Certification: There is an App for That." IEEE Open Journal of Engineering in Medicine and Biology 1, no. 1 (June 2020): 148-155.

9. Fidler, D., P. “Vaccine nationalism's politics", Science 369, no. 6505 (August 2020): 749-755.

10. Garcia-Morato, L., L., D. "Mutual recognition of professional qualifications in the European Union: Legal protection and administrative cooperation." Revista general de derecho europeo 30, no. 51 (May 2020): article no. 422516. 
11. Greely, H., T. "COVID-19 immunity certificates: science, ethics, policy and law", Journal of Law and the Biosciences 7, no. 1 (June 2020): Isaa0035.

12. Gruszczynski, L., Wu, Ch., "Between the High Ideals and Reality: Managing COVID19 Vaccination Nationalism", European Journal of Risk Regulation, available at: https://doi.org/10.1017/err.2021.9.

13. Handrlica, J. “A treatise for international administrative law." Lawyer Quarterly 10, no. 4 (December 2020): 462-475.

14. Handrlica, J. "Is there an EU international administrative law? A juristic delusion revisited." European Journal of Legal Studies 12, no. 2 (October 2020): 79-116.

15. Handrlica, J. “Two faces of „international administrative law.” Tribuna Juridica Juridical Tribune 9, no. 2 (April 2019): 363-376.

16. Handrlica, J. "Revisiting international administrative law as a legal discipline." Zbornik Pravnog Fakulteta Sveučilišta u Rijeci 39, no. 3 (December 2018): 1237-1258.

17. Heller, D. "Toward One Baptism: The Discussions on Mutual Recognition of Baptism in an International Perspective", Ecumenical Review 67, no. 3 (October 2015): 436-449.

18. Hemler, A, Die Methodik der „Eingriffsnorm “ im modernen Kollisionsrecht. Tübingen: Mohr Siebeck, 2019.

19. Hunt, A., T. "Authentication of international vaccination certificates." British Medical Journal 2, no. 5869 (1973): 781-782.

20. Jakab, R. "Defense of an EU member state against effects of trasnational administrative acts." Tribuna Juridica - Juridical Tribune 10, Special issue (September 2020): 32-48.

21. Jarck, Ch., Abänderung und Aufhebung ausländischer Staatshoheitsakte im internationalen Rechtsverkehr. Göttingen: Georg-August Universität, 1954.

22. Kerber, W., Van den Bergh, R. "Mutual Recognition Revisited: Misunderstandings, Inconsistencies, and a Suggested Reinterpretation", Kyklos 61, no. 3 (August 2008): 447-468.

23. Kofler, N., Baylis, F., "Examining "immunity passports" from an ethics perspective ten reasons why they are a bad idea." European Journal of Public Health 30, supplement 5 (September 2020): v185-v185.

24. Liew, Ch., H., Flaherty, G., T. "Immunity passports to travel during the COVID-19 pandemic: controversies and public health risks." Journal of Public Health 43, no. 1 (March 2021): e135-e136.

25. Maier-Rigaud, F., "Umbrella effects and the ubiquity of damage resulting from competition law violations." Journal of European Competition Law and Practice 5, no. 4 (April 2015): 247-251.

26. Marhold, K., Fell, J., "Electronic vaccination certificates", Nature Medicine, available at 10.1038/s41591-021-01286-w.

27. Miguel Beriain, I., Rueda, J. "Vaccination certificates, immunity passports and testbased travel licences: Ethical, legal and public health issues." Travel Medicine and Infectious Disease 42 (July 2021): 102079.

28. Miguel Beriain, I., Rueda, J. "Immunity passports, fundamental rights and public health hazards" Journal of Medical Ethics 46, no. 10 (October 2020): 660-661

29. Moestl, M. "The Principle of Mutual Recognition in EU Law." Common Market Law Review 52, no. 4 (August 2015): 1147-1148.

30. Mortelmans, K. "The principle of equivalence or "mutual regognition" in community law." Common Market Law Review 34, no. 3 (June 1997): 754-755.

31. Neumeyer, K. Internationales Verwaltungsrecht. Allgemeiner Teil. München: Verlag J. Schweitzer, 1936. 
32. Ngern, T. "One Baptism: Towards Mutual Recognition”, Journal of Ecumenical Studies 49, no. 2 (September 2014): 362-363.

33. Oehler, C. Die Kollisionsordnung des Allgemeinen Verwaltungsrecht. Strukturen des deutschen Internationalen Verwaltungsrechts. Tübingen: Mohr Siebeck, 2019.

34. Osama, T., Razai, M., S., Majeed, A. "Covid-19 vaccine passports: Access, equity and ethics", The BMJ 373 (April 2021): n861.

35. Pacces, A., Weimer, M. "From Diversity to Coordination: A European Approach to COVID-19." European Journal of Risk Regulation 11, no. 2 (June 2020): 283-296.

36. Parisi, F., Ghei, N. "The role of reciprocity in international law." Cornell International Law Journal 36, no. 1 (September 2003): 93-123.

37. Persad, G., Emanuel, E. "The Ethics of COVID-19 Immunity-Based Licenses ("Immunity Passports")." Journal of the American Medical Association 323, no. 22 (June 2020): 2241-2242.

38. Petersen, E., Lucey, D., Blumberg, L. et al, "COVID-19 vaccines under the International Health Regulations - We Must Use the WHO International Certificate of Vaccination or Prophylaxis" International Journal of Infectious Diseases 104 (March 2021): 175-177.

39. Phelan, A., L. "COVID-19 immunity passports and vaccination vertificates: scientific, equitable and legal challenges." The Lancet 395, issue 10237 (May 2020): 1595-1598.

40. Ruffert, M. "Recognition of Foreign Legislative and Administrative Acts." In Max Plack Encyclopedia of Public International Law, edited by Rüdiger Wolfrum, 567-578. Oxford: Oxford University Press, 2008.

41. Ruiz-Yamuza, F., G. "Requiem for the principle of mutual trust?" Revista general de derecho europeo 20, no. 43 (October 2017): 201-245.

42. Salter, M. Rights of Passage: The Passport in International Relations. London: Lynne Rienner Publishers, 2003.

43. Schlagenhauf, P., Patel, D., Rodriquez-Morales, A., Gautret, P., Grobusch, M., Leder, K. "Variants, vaccines and vaccination passports." Travel Medicine and Infectious Disease 40, article number 101996 (March 2021): https://doi.org/ 10.1016/j.tmaid.2021.101996.

44. Spaventa, E. "Mutual recognition and conflict of law rules." Common Market Law Review 40, no. 6 (December 2003): 1562-1564.

45. Streinz, T. "The Principle of Mutual Recognition in EU Law." Journal of Common Market Studies 52, no. 5 (September 2014): 1166-1167.

46. Southern, R., W. "The Changing Role of Universities in Medieval Europe." Historical Research 60, no. 142 (June 1987): 133-146.

47. Tsoi, K., K. et al, "The way forward after COVID-19 vaccination: Vaccine passports", BMJ Innovations 7, no. 2 (April 2021): 337-341.

48. Vogel, K. Der räumliche Anwendungsbereich der Verwaltungsnorm. Eine Untersuchung über die Grundlagen des sog. Internationalen Verwaltungs- und Steuerrechts. Frankfurt/Main: Alfred Metzner Verlag, 1965.

49. Wilder-Smith, A., Hill, D., R. "International certificate of vaccination or prophylaxis." The Lancet 370, no. 9587 (August 2007): 565-566. 